\title{
Residual feed intake in beef cattle and its association with carcass traits, ruminal solid-fraction bacteria, and epithelium gene expression
}

Ahmed A. Elolimy ${ }^{1,2}$, Mohamed K. Abdelmegeid ${ }^{1,2,3}$, Joshua C. McCann², Daniel W. Shike ${ }^{2}$ and Juan J. Loor ${ }^{1,24^{*}}$ (1)

\begin{abstract}
Background: Residual feed intake (RFI) describes an animal's feed efficiency independent of growth performance. The objective of this study was to determine differences in growth performance, carcass traits, major bacteria attached to ruminal solids-fraction, and ruminal epithelium gene expression between the most-efficient and the least-efficient beef cattle. One-hundred and forty-nine Red Angus cattle were allocated to three contemporary groups according to sex and herd origin. Animals were fed a finishing diet in confinement for $70 \mathrm{~d}$ to determine the RFI category for each. Within each group, the two most-efficient ( $n=6$; RFI coefficient $=-2.69 \pm 0.58 \mathrm{~kg}$ dry matter intake (DMI)/d) and the two least-efficient animals ( $n=6$; RFI coefficient $=3.08 \pm 0.55 \mathrm{~kg} \mathrm{DMI} / \mathrm{d}$ ) were selected. Immediately after slaughter, ruminal solids-fraction and ruminal epithelium were collected for bacteria relative abundance and epithelial gene expression analyses, respectively, using real-time PCR.
\end{abstract}

Results: The most-efficient animals consumed less feed $(P=0.01 ; 5.03 \mathrm{~kg}$ less DMl/d) compared with the leastefficient animals. No differences $(P>0.10)$ in initial body weight (BW), final BW, and average daily gain (ADG) were observed between the two RFI classes. There were no significant RFI $\times$ sex effects $(P>0.10)$ on growth performance. Compared with the least-efficient group, hot carcass weight $(\mathrm{HCW})$, ribeye area (REA), and kidney, pelvic, and heart fat $(\mathrm{KPH})$ were greater $(P \leq 0.05)$ in the most-efficient cattle. No RFI $\times$ sex effect $(P>0.10)$ for carcass traits was detected between RFI groups. Of the 10 bacterial species evaluated, the most-efficient compared with least efficient cattle had greater $(P \leq 0.05)$ relative abundance of Eubacterium ruminantium, Fibrobacter succinogenes, and Megasphaera elsdenii, and lower $(P \leq 0.05)$ Succinimonas amylolytica and total bacterial density. No RFI $\times$ sex effect on ruminal bacteria was detected between RFI groups. Of the 34 genes evaluated in ruminal epithelium, the mostefficient cattle had greater $(P \leq 0.05)$ abundance of genes involved in VFA absorption, metabolism, ketogenesis, and immune/inflammation-response. The RFI $\times$ sex interactions indicated that responses in gene expression between RFI groups were due to differences in sex. Steers in the most-efficient compared with least-efficient group had greater $(P \leq 0.05)$ expression of SLC9A1, HIF1A, and ACO2. The most-efficient compared with least-efficient heifers had greater $(P \leq 0.05)$ mRNA expression of BDH1 and lower expression $(P \leq 0.05)$ of SLC9A2 and PDHA1.

(Continued on next page)

\footnotetext{
* Correspondence: jloor@illinois.edu

${ }^{1}$ Mammalian NutriPhysioGenomics, Department of Animal Sciences, University of Illinois, Urbana, IL, USA

${ }^{2}$ Department of Animal Sciences, University of Illinois, Urbana, IL, USA

Full list of author information is available at the end of the article
}

(c) The Author(s). 2018 Open Access This article is distributed under the terms of the Creative Commons Attribution 4.0 International License (http://creativecommons.org/licenses/by/4.0/), which permits unrestricted use, distribution, and reproduction in any medium, provided you give appropriate credit to the original author(s) and the source, provide a link to the Creative Commons license, and indicate if changes were made. The Creative Commons Public Domain Dedication waiver (http://creativecommons.org/publicdomain/zero/1.0/) applies to the data made available in this article, unless otherwise stated. 
(Continued from previous page)

Conclusions: The present study revealed that greater feed efficiency in beef cattle is associated with differences in bacterial species and transcriptional adaptations in the ruminal epithelium that might enhance nutrient delivery and utilization by tissues. The lack of RFI $\times$ sex interaction for growth performance and carcass traits indicates that sex may not play a major role in improving these phenotypes in superior RFI beef cattle. However, it is important to note that this result should not be considered a solid biomarker of efficient beef cattle prior to further examination due to the limited number of heifers compared with steers used in the study.

Keywords: Beef cattle, Carcass, Gene expression, Growth, RFI, Ruminal bacteria, Ruminal epithelium, Sex,

\section{Background}

The concept of residual feed intake (RFI), which is a commonly used measure for the efficiency of feed utilization in cattle independent from body weight (BW) and the level of production, was proposed more than 50 years ago by Koch et al. [1]. RFI is defined as the difference between the actual dry matter intake (DMI) of an animal and the expected DMI required for maintenance and growth estimated through a regression equation involving metabolic BW and average daily gain (ADG) [1]. The primary advantage of identifying the most-efficient animals (i.e., with low RFI) is to reduce DMI in beef systems without compromising growth performance because feed-related costs represent the largest production expense in beef production [2]. Any reduction in DMI to produce a unit of beef product would minimize feed costs, resulting in maximizing the overall profitability of beef industry.

A previous study indicated that $\sim 20 \%$ of RFI variation in beef cattle could be explained by differences in rumen-related functions such as microbial digestion and epithelial metabolism [3]. Evidence indicates that efficient beef bulls and heifers have greater digestibility for dry matter (DM), organic matter (OM), neutral detergent fiber (NDF), protein, and total digestible nutrients (TDN) $[4,5]$, underscoring the vital role of ruminal microbes and epithelial tissue as key drivers of divergence in RFI. Thus, additional work to evaluate ruminal microbes and epithelium tissue between divergent RFI classes should help in identifying potential physiological mechanisms to enhance nutrient uptake and production efficiency in the most-efficient cattle.

The association between changes in ruminal bacteria profile and RFI divergence has been suggested previously. For example, compared with the least-efficient, the most-efficient Brahman bulls had greater abundance of Bacteroidales but lower Prevotella [6]. In a recent study, Liang et al. [7] reported that the most-efficient lambs had lower Butyrivibrio fibrisolvens and Escherichia coli. The association between feed efficiency in beef cattle and changes in ruminal epithelium gene transcription was addressed recently. Kong et al. [8] reported that, compared with the least-efficient, the most-efficient finishing steers had greater expression of genes involved in VFA absorption (dynamin-2 (DNM2); tubulin beta-5 (TUBB5); tubulin alpha-4a $(T U B A 4 A))$. A greater expression of genes involved in cell growth and proliferation such as solute carrier family 26 member 3 (SLC26A3), caveolin 1 (CAV1), NAD $(\mathrm{P}) \mathrm{H}$ quinone dehydrogenase 1 (NQO1), and regulator of $\mathrm{G}$ protein signaling 5 (RGS5) was detected in steers classified as high gain-low feed intake compared with least-efficient steers [9].

Most of the available RFI studies in beef cattle are limited to either steers or heifers, hence, the association between RFI and sex also warrants further investigation. It was hypothesized that holistic evaluation of the relationship between RFI and ruminal function, including ruminal bacteria and epithelial responses, in both steers and heifers would provide insights into biological mechanisms underpinning variation in RFI divergence between sexes. Such data would also help to uncover biomarkers for identifying the most-efficient animals. We addressed these issues using Red Angus beef steers and heifers classified as most- or least-efficient during a 70-d finishing period. Major ruminal bacteria that play key roles in cellulose digestion (Fibrobacter succinogenes, Eubacterium ruminantium) [10, 11], hemicellulose breakdown (Prevotella bryantii) [12], xylan degradation (Butyrivibrio proteoclasticus) [13], starch consumption (Succinimonas amylolytica, Streptococcus bovis, Succinovibrio dextrinosolvens) [14], lactate utilization (Megasphaera elsdenii, Selenomonas ruminantium) $[15,16]$, and ruminal biohydrogenation (Anaerovibrio lipolytica) [17] were quantified in the rumen-solids fraction. Additionally, the abundance of rumen epithelial genes playing key roles in VFA absorption [18], metabolism [19, 20], ketogenesis $[21,22]$, and immune/inflammation-response [23] that could be affected by the changes in feed intake between RFI groups were measured at slaughter.

\section{Methods}

All the procedures for this study were approved by Institutional Animal Care and Use Committee of the University of Illinois under protocol number 12009. 


\section{Animals, experimental design, and diets}

Three contemporary groups of Red Angus cattle (Group 1: 35 steers; Group 2: 37 heifers; Group 3: 80 steers) were used. Animal BW was recorded on 2 consecutive days at the beginning of the RFI test and averaged to determine initial BW. Animals were blocked in group pens based on their initial BW to limit domination. Each pen was equipped with GrowSafe ${ }^{\circ}$ individual feed intake system (GrowSafe Systems Ltd., Alberta, Canada) allowing for individual intake data. Upon blocking the animals, electronic identification tags were attached to the left ear to help in tracking individual feed intake. The experimental period had a duration of $70 \mathrm{~d}$ ( $21 \mathrm{~d}$ of adaptation to traditional mid-west finishing feedlot diet and environment $+70 \mathrm{~d}$ of data collection). The experimental diet was formulated to meet all nutrient requirements for growing cattle according to NRC (Table 1). The experimental diet was fed in excess to achieve on average $5 \%$ of refusal daily. It was offered twice daily and all animals had ad libitum access to feed and water throughout the experimental period.

\section{Animal feedlot test and RFI calculation}

The BW, ADG, midpoint metabolic weight (MMW), and DMI were calculated for each animal as described

Table 1 Diet and nutrient composition fed to finishing cattle on RFI testing for $70 \mathrm{~d}$

\begin{tabular}{|c|c|}
\hline Items & Inclusion, \% DM \\
\hline \multicolumn{2}{|l|}{ Ingredient, \% } \\
\hline High-moisture corn & 20.00 \\
\hline Cracked corn & 40.00 \\
\hline Corn silage & 20.00 \\
\hline DDGS $^{1}$ & 10.00 \\
\hline Supplement, \% of DM & 10.00 \\
\hline Ground corn & 76.19 \\
\hline Urea & 5.99 \\
\hline Limestone & 15.89 \\
\hline Dairy trace mineral sal ${ }^{\mathrm{t} 2}$ & 0.91 \\
\hline Rumensin $90^{3}$ & 0.15 \\
\hline Tylan $40^{4}$ & 0.10 \\
\hline Vitamin A-V blend & 0.77 \\
\hline \multicolumn{2}{|l|}{ Analyzed nutrient content, \% } \\
\hline $\mathrm{CP}$ & 15.62 \\
\hline NDF & 20.82 \\
\hline ADF & 8.17 \\
\hline Fat & 3.71 \\
\hline
\end{tabular}

'Dried distillers grains with solubles

${ }^{2}$ Contained $8.5 \% \mathrm{Ca}$ (as $\mathrm{CaCO}_{3}$ ), $5 \% \mathrm{Mg}$ (as $\mathrm{MgO}$ and $\mathrm{MgSO}_{4}$ ), $7.6 \% \mathrm{~K}$ (as $\mathrm{KCl}$ ), $6.7 \% \mathrm{Cl}$ (as KCl), $10 \% \mathrm{~S}$ (as $\mathrm{S}_{8}$, prilled), $0.5 \% \mathrm{Cu}$ (as $\mathrm{CuSO}_{4}$ and Availa-4; Zinpro Performance Minerals; Zinpro Corp, Eden Prairie, MN)

${ }^{3}$ Elanco Animal Health, Greenfield, IN

${ }^{4}$ Elanco Animal Health, Greenfield, IN previously [24]. Briefly, all animals were weighed at the beginning, end and at every $14 \mathrm{~d}$ of the experimental period prior to feeding to minimize differences in gut fill but with no food and water restriction. The ADG was estimated as the slope of the linear regression between BW and days on feed. Midpoint metabolic weight was calculated as midpoint $\mathrm{BW}^{0.75}$, with midpoint $\mathrm{BW}$ computed as the sum of the initial BW and the product of ADG multiplied by half of the days on RFI test. The DMI for each animal was recorded daily via the Grow$\mathrm{Safe}^{\circ}$ system. After the end of the collection of feed intake data, cattle had access to the same diet ad libitum and remained in the same pens for $30 \mathrm{~d}$ until reaching $1.15 \mathrm{~cm}$ backfat depth measured by ultrasound.

Animals were slaughtered after a 16-h fast. Hot carcass weight $(\mathrm{HCW})$ was recorded, and kidney, pelvic, and heart fat $(\mathrm{KPH})$, ribeye area (REA), backfat thickness $(\mathrm{BFT})$, and marbling score $(100=$ practically devoid, 200 $=$ traces, $300=$ slight, $400=$ small, $500=$ modest, $600=$ moderate,$\quad 700=$ slightly abundant,$\quad 800=$ moderately abundant) collected after a 24-h chill at $-4{ }^{\circ} \mathrm{C}$. Amount of boneless, closely-trimmed retail cuts from the high-value parts of the carcass (round, loin, rib, and chuck), i.e. USDA yield grade (YG), was calculated by evaluating the amount of $\mathrm{HCW}, \mathrm{KPH}, \mathrm{BFT}$, and REA. Growth performance and carcass traits are shown in Table 2.

\section{Ruminal digesta and tissue sampling}

After slaughter, the rumen from the most- and the least-efficient animals was immediately removed and sampling of the solids-fraction and epithelium performed. Mixed ruminal contents were collected and squeezed through 4-layers of cheesecloth allowing the separation of solids from the liquid fraction before sampling and placing in $50 \mathrm{~mL}$ sterilized tubes. The ruminal rumen papillae was excised (approximately $300 \mathrm{mg}$ ) from the central region of the ventral sac [8], and immediately washed with PBS before placing in $1.5 \mathrm{~mL}$ sterilized tubes. All samples were immediately snap-frozen in liquid nitrogen, transported to the laboratory. Rumen solids-fraction was stored at $-20^{\circ} \mathrm{C}$ and ruminal epithelium stored at $-80^{\circ} \mathrm{C}$ until further analysis.

\section{Ruminal bacteria DNA extraction and the amplification of 16S rRNA genes}

The procedure for extraction of bacteria attached to the solids-fraction was as previously described [25]. Briefly, $25 \mathrm{~g}$ of sample was added into $100 \mathrm{~mL}$ of chilled extraction buffer composed of $100 \mathrm{mmol} / \mathrm{L}$ Tris/HCl, $10 \mathrm{mmol} / \mathrm{L}$ EDTA, $0.15 \mathrm{~mol} / \mathrm{L} \mathrm{NaCl}$ at $\mathrm{pH}$ of 8.0. The mixture was homogenized by polytron (Kinematica Inc., Bohemia, NY, USA) for $2 \mathrm{~min}$, then centrifuged at $500 \times g$ 
Table 2 Growth and carcass traits of the most- $(n=6)$ and the least- $(n=6)$ efficient beef cattle on RFI testing for $70 \mathrm{~d}$ during the finishing period

\begin{tabular}{|c|c|c|c|c|c|c|c|c|c|}
\hline \multirow[t]{2}{*}{ Items } & \multicolumn{2}{|l|}{$\mathrm{RFI}^{1}$} & \multirow[t]{2}{*}{$\mathrm{SE}^{2}$} & \multicolumn{2}{|l|}{ Sex } & \multirow[t]{2}{*}{$\mathrm{SE}^{3}$} & \multicolumn{3}{|c|}{$P$-value } \\
\hline & Most-efficient animals & Least-efficient animals & & Steers & Heifers & & $\mathrm{RFI}$ & Sex & $\mathrm{RFI} \times \operatorname{sex}$ \\
\hline \multicolumn{10}{|l|}{ Growth performance } \\
\hline Initial BW, kg & 814.25 & 836.06 & 45.95 & 847.31 & 803.00 & 53.05 & 0.75 & 0.52 & 0.87 \\
\hline Final BW, kg & 1124.25 & 1173.63 & 64.77 & 1189.88 & 1108.00 & 74.79 & 0.61 & 0.40 & 0.59 \\
\hline $\mathrm{MMW}^{4}, \mathrm{~kg}^{0.75}$ & 173.06 & 166.39 & 5.93 & 179.50 & 159.95 & 6.85 & 0.45 & 0.05 & 0.43 \\
\hline$A D G, k g / d$ & 1.83 & 1.77 & 0.13 & $2.02^{\mathrm{a}}$ & $1.57^{b}$ & 0.15 & 0.75 & 0.04 & 0.91 \\
\hline DMI, kg/d & $18.36^{\mathrm{b}}$ & $23.39^{a}$ & 1.13 & 22.62 & 19.13 & 1.24 & 0.01 & 0.06 & 0.77 \\
\hline RFI coefficient, kg/d & $-2.69^{b}$ & $3.08^{\mathrm{a}}$ & 0.58 & 0.35 & 0.043 & 0.63 & $<0.01$ & 0.71 & 0.52 \\
\hline \multicolumn{10}{|l|}{ Carcass traits } \\
\hline $\mathrm{HCW}^{5}, \mathrm{~kg}$ & $357.56^{\mathrm{a}}$ & $323.53^{b}$ & 9.61 & $367.26^{\mathrm{a}}$ & $313.83^{b}$ & 10.52 & 0.04 & $<0.01$ & 0.66 \\
\hline $\mathrm{KPH}^{6}, \%$ & $2.69^{a}$ & $2.25^{\mathrm{b}}$ & 0.14 & $2.06^{b}$ & $2.88^{\mathrm{a}}$ & 0.14 & 0.05 & $<0.01$ & 0.33 \\
\hline $\mathrm{REA}^{7}, \mathrm{~cm}^{2}$ & $89.40^{a}$ & $78.52^{\mathrm{b}}$ & 3.20 & 85.17 & 82.74 & 3.51 & 0.04 & 0.58 & 0.62 \\
\hline $\mathrm{BFT}^{8}, \mathrm{~mm}$ & 12.19 & 11.81 & 1.58 & 11.81 & 12.19 & 1.82 & 0.87 & 0.87 & 0.48 \\
\hline Marbling score ${ }^{9}$ & 457.5 & 442.5 & 20.63 & $407.5^{b}$ & $492.5^{a}$ & 23.82 & 0.62 & 0.02 & 0.21 \\
\hline$Y G^{10}$ & 2.45 & 2.97 & 0.34 & 2.87 & 2.56 & 0.39 & 0.32 & 0.54 & 0.73 \\
\hline
\end{tabular}

Means with different superscripts $\left({ }^{\mathrm{a}, \mathrm{b}}\right)$ within row represent differences among overall RFI or sex effects $(P \leq 0.05)$

${ }^{1} R F I$ residual feed intake

${ }^{2} S E$ standard error of the mean for RFI effect

${ }^{3} S E$ standard error of the mean for sex effect

${ }^{4} \mathrm{MMW}$ midpoint metabolic weight

${ }^{5} \mathrm{HCW}$ hot carcass weight

${ }^{6} \mathrm{KPH}$ kidney, pelvic, and heart

${ }^{7} R E A$ ribeye area

${ }^{8} B F T$ backfat thickness

${ }^{9}$ For marbling score $100=$ practically devoid, $200=$ traces, $300=$ slight, $400=$ small, $500=$ modest, $600=$ moderate, $700=$ slightly abundant, $800=$ moderately abundant

${ }^{10} \mathrm{YG}$ yield grade $=2.5+0.984 \times \mathrm{BFT}(\mathrm{cm})+0.20 \times \mathrm{KPH}(\%)+0.0084 \times \mathrm{HCW}(\mathrm{kg})-0.0497 \times \mathrm{LM}$ area $\left(\mathrm{cm}^{2}\right)[67]$

for $15 \mathrm{~min}$ at $4{ }^{\circ} \mathrm{C}$ to keep bacterial cells in the supernatant. The resulting supernatant was centrifuged at $10,000 \times g$ for $25 \mathrm{~min}$ at $4{ }^{\circ} \mathrm{C}$. The pellet was harvested, freeze-dried, and stored at $-20{ }^{\circ} \mathrm{C}$. Twentyfive $\mathrm{mg}$ of the pellet was used to isolate total genomic DNA using the repeated bead-beating plus column method described by $\mathrm{Yu}$ and Morrison [26] for mechanical lysis of bacterial cell wall employing the QIAamp DNA mini kit (QIAGEN, CA, USA) for DNA purification. The DNA quantity and quality were checked using $0.8 \%(w t / v)$ agarose gel electrophoresis and NanoDrop spectrophotometer (ND 1000, NanoDrop Technologies, Inc., Wilmington, DE, USA) at $260 \mathrm{~nm}$. Extracted DNA was standardized to $8 \mathrm{ng} / \mu \mathrm{L}$ for quantitative PCR (qPCR) reactions.

Primers were selected to amplify 10 of major ruminal bacteria species play key roles in cellulose and hemicellulose digestion, xylan degradation, proteolysis, propionate production, lactate utilization and ruminal biohydrogenation [27], as listed in Additional file 1. A total of $10 \mu \mathrm{L}$ of qPCR mixture contained $4 \mu \mathrm{L}$ sample DNA, $5 \mu \mathrm{L} 1 \times$ SYBR Green with ROX (Quanta BioSciences, Gaithersburg, MD, USA), $0.4 \mu \mathrm{L}$ each of $10 \mu \mathrm{mol} /$ $\mathrm{L}$ forward and reverse primers, and $0.2 \mu \mathrm{L}$ DNase/RNase free water in a MicroAmpTM Optical 384-Well Reaction Plate (Applied Biosystems, Foster City, CA, USA). Negative controls without template DNA and samples were run on the same plate in triplicate. The qPCR reactions were performed with ABI PRISM 7900HT Sequence Detection System (Applied Biosystems, Foster City, CA, USA) using the following program: initial denaturation at $95{ }^{\circ} \mathrm{C}$ for $5 \mathrm{~min}$, followed by 40 cycles of $1 \mathrm{~s}$ at $95{ }^{\circ} \mathrm{C}$ and $30 \mathrm{~s}$ annealing at $60{ }^{\circ} \mathrm{C}$. A final dissociation stage was performed to determine the specificity of the amplification. Relative abundance of bacterial species, including Anaerovibrio lipolytica, Butyrivibrio proteoclasticus, Eubacterium ruminantium, Fibrobacter succinogenes, Megaspheara elsdenii, Prevotella bryantii, Selenomonas ruminantium, Succinimonas amylolytica, Streptococcus bovis, and Succinivibrio dextrinosolvens, was calculated using the geometric mean of two universal primers of bacteria general 1 and bacteria general 2 [28, 29] (Additional file 1) with the efficiency-corrected $\Delta^{-\mathrm{CT}}$ method [30]. The copy number of total bacterial 16S rRNA genes in rumen solids-fraction was measured to estimate the total bacterial density using qPCR with the bacteria general 3 (Additional file 1) which was commercially synthesized (IDT, Coralville, IA, USA) 
to target the universal bacteria, following a procedure described previously [31].

\section{Ruminal epithelium RNA extraction and cDNA synthesis}

Ten $\mathrm{mg}$ tissue was immediately placed in $1.2 \mathrm{~mL}$ QIAzol Lysis Reagent (Qiagen, Valencia, CA, USA) and homogenized with $5 \mathrm{~mm}$ stainless steel beads using a Mini-Beadbeater (BioSpec Products, Bartlesville, OK, USA) with two $30 \mathrm{~s}$ cycles, and $1 \mathrm{~min}$ incubation on ice in between the cycles. The sample was then centrifuged for $10 \mathrm{~min}$ at $12,000 \times g$ and $4{ }^{\circ} \mathrm{C}$, and the supernatant transferred to a separate tube and mixed with $240 \mu \mathrm{L}$ of chloroform. After centrifugation for $15 \mathrm{~min}$ at 12,000 $\times$ $g$ at $4{ }^{\circ} \mathrm{C}$, the aqueous phase was transferred to a fresh 1.5 centrifuge tube, mixed with $900 \mu \mathrm{L}$ of $100 \%$ ethanol (Decon Laboratories, Inc., King of Prussia, PA, USA). The extracted RNA was cleaned using miRNeasy mini kit columns (Qiagen, Valencia, CA, USA) following the manufacturer's instructions. All samples were treated with DNaseI (Qiagen, Valencia, CA, USA) to remove genomic DNA. Total RNA quantification was determined using a Nanodrop ND-1000 (Nanodrop Technologies, Rockland, DE, USA). The purity and integrity of extracted RNA was evaluated using a Fragment Analyzer (Advanced Analytical, Ames, IA, USA) with an average RIN score of 8.8 (minimum $\mathrm{RIN}=7.4$ ). The RNA was diluted to $100 \mathrm{ng} / \mu \mathrm{L}$ with DNase/RNase-free water. For cDNA synthesis, a mixture of $4 \mu \mathrm{L}$ of diluted RNA, $5 \mu \mathrm{L}$ of Random Primers $(3 \mu \mathrm{g} / \mu \mathrm{L}$; Roche Diagnostics, Basel, Switzerland), and $45 \mu \mathrm{L}$ of DNase/RNase-free water was incubated at $65{ }^{\circ} \mathrm{C}$ for $5 \mathrm{~min}$ and kept on ice for $3 \mathrm{~min}$.

A total of $36 \mu \mathrm{L}$ of master mix composed of $16 \mu \mathrm{L} 5 \times$ Reaction Buffer (Thermo Fisher Scientific, Waltham, MA, USA), $4 \mu \mathrm{L}$ of Oligo dT18 (Custom DNA Oligo Tubes, Integrated DNA Technologies, Coralville, IA, USA), $1 \mu \mathrm{L}$ of RevertAid Reverse Transcriptase (Thermo Fisher Scientific, Waltham, MA, USA), $8 \mu \mathrm{L}$ of $10 \mathrm{mmol} / \mathrm{L}$ dNTP mix (Invitrogen, Carlsbad, CA, USA), $0.5 \mu \mathrm{L}$ of RNase Inhibitor (Thermo Fisher Scientific, Waltham, MA, USA), and $6.5 \mu \mathrm{L}$ of DNase/RNase-free water, was added. The reaction was performed in an Eppendorf Mastercycler ${ }^{\circ}$ Gradient using the following temperature program: $25^{\circ} \mathrm{C}$ for $5 \mathrm{~min}, 42^{\circ} \mathrm{C}$ for $60 \mathrm{~min}$, and $70{ }^{\circ} \mathrm{C}$ for $5 \mathrm{~min}$. The cDNA was then diluted 1:4 with DNase/RNase-free water, prior to quantitative reverse transcription-PCR (qRT-PCR) analysis.

\section{Quantitative PCR}

Complete information about primer sequences and qRT-PCR performance are reported in Additional file 1. Their PCR products were verified using gel electrophoresis and sequencing (data not shown). The qRT-PCR reaction components and instrument conditions were the same as described for bacterial qPCR. All reactions were run in triplicate. A six-point relative standard curve was used to determine gene expression [23]. The most-concentrated standard $(100 \mathrm{ng} / \mu \mathrm{L})$ was prepared by combining $30 \mu \mathrm{L}$ from all samples after converting RNA into cDNA. Using molecular grade water, the subsequent standards were prepared through 1:4 serial dilutions of the most-concentrated standard to eventually get standard 1, 2, 3, 4, 5, and 6 contain 100, 25, 6.250, 1.560, 0.391 , and $0.098 \mathrm{ng} / \mu \mathrm{L}$, respectively, for the standard curve. After the completion of qPCR, Ct value of each sample has been used to calculate the cDNA quantity through the standard curve. Relative quantities were calculated using the geometric mean of previously-validated internal control for work with ruminal epithelium: CKLF like MARVEL transmembrane domain containing 6 (CMTM6), ELKS/ RAB6-interacting/CAST family member 1 (ERC1), and mitochondrial ribosomal protein L39 (MRPL39) $[20,32]$ with the efficiency-corrected $2^{-\Delta \Delta C t}$ method [33]. The gene expression results reported in Table 1 are the $\log _{2}$ back-transformed LSM and standard error.

\section{Statistical analysis}

The RFI was calculated using the PROC MIXED procedure of SAS procedure of SAS 9.4 (SAS Institute Inc., Cary, NC, USA). Animals were separated into 3 contemporary groups using sex and source of origin. RFI was calculated within contemporary group, and assumed to represent the residuals from a multiple regression model regressing DMI on ADG, MMW, and BFT, using pen as a random effect in the following model:

Expected $\quad \mathrm{DMI}=\beta_{0}+\beta_{1} \times \mathrm{ADG}+\beta_{2} \times \mathrm{MMW}+\beta_{3} \times$ $\mathrm{BFT}+\beta_{4}+\varepsilon$.

in which $\beta_{0}$ is the $y$-intercept, $\beta_{1}$ is the partial regression coefficient of ADG, $\beta_{2}$ is the partial regression coefficient of MMW, $\beta_{3}$ is the partial regression coefficient of BFT, $\beta_{4}$ is the random effect of pen and $\varepsilon$ is the error term. The coefficient of determination $\left(R^{2}\right)$ was $0.76,0.65$, and 0.42 for group 1,2 , and 3, respectively. As proposed by Basarab et al. [24], the RFI (kg DMI/d) for each individual animal was then calculated as the difference between the daily DMI and the expected DMI. All animals were ranked by RFI, then the two most extreme low and high RFI animals from each group were selected to form two RFI groups: the most-efficient animals $(n=6)$ and the least-efficient animals $(n=6)$, each composed of 6 extreme animals. Individual animal was the experimental unit, and dependent variables included growth performance, carcass traits, relative abundance of bacteria, and ruminal 
epithelium genes. Model included the fixed effects of RFI category, sex, and RFI $\times$ sex. Separation of LSM for significant effects was accomplished using the Tukey's option within the MIXED procedure of SAS. Logit transformation $(z=\log [p /(1-p)])$ was applied for bacterial abundance to ensure normal distribution of the data, where $p$ represents the relative abundance of a bacterial species. Genes were $\log _{2}$ transformed before statistical analysis but the data were back-transformed for presentation in tables and figures. Significance was declared at $P \leq 0.05$, and trends toward significance were discussed at $0.05<P \leq 0.10$.

\section{Results}

\section{Animal performance and carcass traits}

The mean difference in RFI between the most- and least-efficient animals was $5.77 \mathrm{~kg} \mathrm{DMI} / \mathrm{d}$. The most-efficient animals consumed $2.69 \pm 1.56 \mathrm{~kg} \mathrm{DMI} / \mathrm{d}$ less feed, whereas the least-efficient animals consumed $3.08 \pm$ $1.56 \mathrm{~kg} \mathrm{DMI} / \mathrm{d}$ more feed than expected. The most-efficient group had lower $(P=0.01)$ DMI than least-efficient counterparts. No differences $(P>0.10)$ for initial $\mathrm{BW}$, final $\mathrm{BW}, \mathrm{MMW}$, and ADG were observed between RFI groups (Table 2). There were no significant effect $(P>0.10)$ for the interaction of RFI and sex on growth performance (Table 2). For the sex effect on growth traits, steers had greater MMW $(P=0.05)$ and ADG $(P=$ $0.04)$ and tended to have greater DMI $(P=0.06)$ than heifers. No RFI $\times$ sex interactions $(P>0.10)$ were detected between RFI classes in steers or heifers (Table 2).

A main effect of RFI grouping was detected in carcass traits due to greater $(P \leq 0.05) \mathrm{HCW}, \mathrm{KPH}$, and REA in the most-efficient compared with least-efficient animals (Table 2). Regarding the RFI $\times$ sex effect on carcass traits, no significant differences $(P>0.10)$ were detected (Table 2). With respect to sex effects on carcass traits, there were significant differences between steers and heifers, with steers having greater $\mathrm{HCW}$ but lower $(P \leq$ $0.05) \mathrm{KPH}$ and marbling score (Table 2).

\section{Ruminal bacteria}

Among target bacteria, S. ruminantium and S. dextrinosolvens were the most abundant averaging $0.12 \%$ and $0.11 \%$ of the $16 \mathrm{~S}$ rRNA copy numbers. There was no significant $(P>0.10)$ effect of RFI or sex on A. lipolytica, $B$. proteoclasticus, $P$. bryantii, $S$. ruminantium, $S$. bovis, and $S$. dextrinosolvens. The most-efficient cattle had greater $(P \leq 0.05)$ abundance of E. ruminantium $(218.4 \%), F$. succinogenes (290.0\%), and M. elsdenii (233.3\%), and lower abundance $(P<0.01)$ of $S$. amylolytica $(-81.6 \%)$. The lower $16 \mathrm{~S}$ rRNA gene copy numbers/ng DNA indicated that total ruminal bacteria abundance was lower $(P=$ 0.05 ) in the most-efficient animals (Table 3 ). There was no RFI $\times$ sex effect $(P>0.10)$ on the relative abundance of the selected bacteria or total bacteria density. For the sex effect during the same time-frame, steers compared with heifers had greater relative abundance of E. ruminantium and F. succinogenes (Table 3).

\section{Epithelium gene expression VFA absorption}

Compared with the least-efficient, the most-efficient animals had greater $(P=0.02)$ solute carrier family 16 member 3 (SLC16A3) expression and tended to have greater $(P=0.06)$ solute carrier family 26 member 3 (SLC26A3) expression (Table 4). In contrast, the mostefficient cattle had lower $(P=0.01)$ solute carrier family 9 member A2 (SLC9A2) expression (Table 4). An RFI $\times$ sex effect $(P \leq 0.05)$ was also detected for solute carrier family 9 member A1 (SLC9A1) and hypoxia inducible factor 1 alpha subunit $(H I F 1 A)$ because of greater expression in the most-efficient compared with least-efficient steers, whereas no significant differences $(P>0.10)$ for both genes were detected between RFI classes for heifers (Fig. 1). For the sex effect, compared with heifers, steers tended $(P=0.08)$ to have lower expression of SLC9A1 (Table 4).

\section{VFA metabolism}

Among the 6 genes measured for VFA metabolism, none was significantly affected by RFI classification $(P>0.10)$ (Table 4). Compared with the least-efficient steers, the most-efficient steers had greater $(P=0.02)$ aconitase 2 (ACO2) expression. For the sex effect, compared with heifers, steers had greater solute carrier family 25 member $20(S L C 25 A 20)(P=0.04)$ and tended to have lower expression $(P=0.07)$ of propionyl-CoA carboxylase alpha subunit $(P C C A)$.

\section{Ketogenesis}

Compared with the least-efficient, the most-efficient animals had greater $(P \leq 0.05)$ mRNA expression of 3-hydroxymethyl-3-methylglutaryl-CoA lyase (HMGCL) and 3-hydroxy-3-methylglutaryl-CoA synthase 2 (HMGCS2), whereas acetyl-CoA acetyltransferase 1 (ACAT1) tended to be greater $(P=0.09)$ (Table 4$)$. Sex had no effect on the ketogenic genes $(P>0.10)$. For the RFI $\times$ sex interaction, the most-efficient heifers had greater $(P=0.04)$ 3-hydroxybutyrate dehydrogenase 1 (BDH1) expression compared with the least-efficient heifers.

\section{Pyruvate metabolism}

Compared with the least-efficient, the most-efficient animals had greater $(P=0.02)$ lactate dehydrogenase A $(L D H A)$ expression and tended to have greater $(P=0.09)$ lactate dehydrogenase $\mathrm{B}(L D H B)$, whereas the expression of pyruvate dehydrogenase alpha 1 (PDHA1) was lower $(P=0.02)$ (Table 4$)$. For the RFI $\times$ sex interaction, the most-efficient heifers had lower $(P=0.02)$ PDHA1 expression compared with the least-efficient heifers. 
Table 3 Relative abundance (\%) of 10 targeted rumen bacteria species and the 165 rRNA gene copy numbers of the total rumen bacterial community in the rumen solids-fraction of the most- $(n=6)$ and the least- $(n=6)$ efficient beef cattle on RFI testing for 70 d during the finishing period

\begin{tabular}{|c|c|c|c|c|c|c|c|c|c|}
\hline \multirow[t]{2}{*}{ Items $^{1}$} & \multicolumn{2}{|l|}{$\mathrm{RFI}^{2}$} & \multirow[t]{2}{*}{$\mathrm{SE}^{3}$} & \multicolumn{2}{|l|}{ Sex } & \multirow[t]{2}{*}{$\mathrm{SE}^{4}$} & \multicolumn{3}{|c|}{$P$-value } \\
\hline & $\begin{array}{l}\text { Most-efficient } \\
\text { animals }\end{array}$ & $\begin{array}{l}\text { Least-efficient } \\
\text { animals }\end{array}$ & & Steers & Heifers & & RFI & Sex & $\begin{array}{l}\text { RFIX } \\
\text { sex }\end{array}$ \\
\hline \multicolumn{10}{|l|}{ Target bacterial species } \\
\hline A. lipolytica & $1.80 \times 10^{-4}$ & $9.00 \times 10^{-5}$ & 0.27 & $\begin{array}{l}1.20 \times \\
10^{-4}\end{array}$ & $\begin{array}{l}1.30 \times \\
10^{-4}\end{array}$ & 0.31 & 0.48 & 0.96 & 0.45 \\
\hline B. proteoclasticus & $1.91 \times 10^{-2}$ & $1.12 \times 10^{-2}$ & 0.22 & $\begin{array}{l}1.33 \times \\
10^{-2}\end{array}$ & $\begin{array}{l}1.60 \times \\
10^{-2}\end{array}$ & 0.25 & 0.47 & 0.80 & 0.66 \\
\hline E. ruminantium & $9.13 \times 10^{-2 a}$ & $4.18 \times 10^{-2 b}$ & 0.10 & $\begin{array}{l}9.09 \times \\
10^{-2 a}\end{array}$ & $\begin{array}{l}4.20 \times \\
10^{-2 b}\end{array}$ & 0.11 & 0.05 & 0.05 & 0.84 \\
\hline F. succinogenes & $2.90 \times 10^{-4 a}$ & $1.00 \times 10^{-4 b}$ & 0.13 & $\begin{array}{l}3.00 \times \\
10^{-4 a}\end{array}$ & $\begin{array}{l}0.90 \times \\
10^{-4 b}\end{array}$ & 0.14 & 0.03 & 0.02 & 0.79 \\
\hline M. elsdenii & $7.00 \times 10^{-5 a}$ & $3.00 \times 10^{-5 b}$ & 0.12 & $\begin{array}{l}4.00 \times \\
10^{-5}\end{array}$ & $\begin{array}{l}5.00 \times \\
10^{-5}\end{array}$ & 0.12 & 0.04 & 0.73 & 0.35 \\
\hline P. bryantii & $4.31 \times 10^{-2}$ & $3.52 \times 10^{-2}$ & 0.14 & $\begin{array}{l}5.37 \times \\
10^{-2}\end{array}$ & $\begin{array}{l}2.82 \times \\
10^{-2}\end{array}$ & 0.16 & 0.67 & 0.20 & 0.40 \\
\hline S. ruminantium & $1.25 \times 10^{-1}$ & $1.17 \times 10^{-1}$ & 0.08 & $\begin{array}{l}1.21 \times \\
10^{-1}\end{array}$ & $\begin{array}{l}1.20 \times \\
10^{-1}\end{array}$ & 0.09 & 0.80 & 0.97 & 0.95 \\
\hline S. amylolytica & $0.70 \times 10^{-4 b}$ & $3.80 \times 10^{-4 a}$ & 0.14 & $\begin{array}{l}2.40 \times \\
10^{-4}\end{array}$ & $1.20 \times$ & 0.14 & $\begin{array}{l}< \\
0.01\end{array}$ & 0.16 & 0.83 \\
\hline S. bovis & $5.63 \times 10^{-3}$ & $6.75 \times 10^{-3}$ & 0.25 & $\begin{array}{l}6.30 \times \\
10^{-3}\end{array}$ & $\begin{array}{l}6.03 \times \\
10^{-3}\end{array}$ & 0.29 & 0.83 & 0.96 & 0.48 \\
\hline S. dextrinosolvens & $4.81 \times 10^{-2}$ & $1.22 \times 10^{-2}$ & 0.48 & $\begin{array}{l}1.38 \times \\
10^{-2}\end{array}$ & $\begin{array}{l}4.26 \times \\
10^{-2}\end{array}$ & 0.56 & 0.41 & 0.49 & 0.28 \\
\hline \multicolumn{10}{|l|}{ Bacteria density } \\
\hline $\begin{array}{l}\text { The } 16 \mathrm{~S} \text { rRNA gene copy numbers }\left(\log _{10}\right) / \mathrm{ng} \\
\text { DNA }^{5}\end{array}$ & $8.03^{b}$ & $8.07^{\mathrm{a}}$ & 0.01 & 8.05 & 8.05 & 0.01 & 0.05 & 0.89 & 0.60 \\
\hline
\end{tabular}

Means with different superscripts $\left({ }^{\mathrm{a}, \mathrm{b}}{ }^{\mathrm{b}}\right)$ within row represent differences among overall RFI or sex effects $(P \leq 0.05)$

${ }^{1}$ Data were logit transformed to ensure normality of residuals

${ }^{2} R F I$ residual feed intake

${ }^{3} S E$ standard error of the mean for RFI effect

${ }^{4} S E$ standard error of the mean for sex effect

${ }^{5} 16 \mathrm{~S}$ rRNA gene copy number $\left(\log _{10}\right) /$ ng DNA

\section{Other metabolic pathways and immune response}

Compared with the least-efficient, the most-efficient animals had greater $(P=0.01)$ expression of peroxisome proliferator activated receptor delta $(P P A R D)$ and tended to have greater $(P=0.09)$ expression of free fatty acid receptor 2 (FFAR2) (Table 4). For the sex effect, steers had lower $(P \leq 0.01) \quad F F A R 2$ in comparison with heifers (Table 4$)$. For the RFI $\times$ sex interaction, the most-efficient steers had greater $(P \leq 0.05)$ expression of FFAR2 compared with the least-efficient steers, but no differences were detected for FFAR2 between RFI groups for heifers $(P>0.10)$. The expression of the immune-responsive toll like receptor 2 (TLR2) and toll like receptor 4 (TLR4) was not affected $(P>0.10)$ by RFI, sex, or RFI $\times$ sex interaction.

\section{Discussion}

Animal performance and carcass traits

Compared with the least-efficient animals, the greater HCW and REA observed in the most-efficient animals is in line with several studies investigating the relationship between RFI grouping and protein deposition in beef cattle $[34,35]$. The similar marbling score and BFT between RFI groups was driven primarily by the lack of enough biological replicates as carcass composition was not the main objective of the study. Other studies found that marbling was greater in the least-efficient steers [36, 37]. Despite this, in the future, it will be important to determine with greater numbers of animals whether lower DMI in feed-efficient cattle is associated with differences in intramuscular fat. With that type of information we could better address the issue of whether the control of marbling in feed-efficient cattle occurs primarily at the tissue level.

\section{Ruminal bacteria}

Several studies indicated that superior feed efficiency (RFI) in beef steers is associated with shifts in rumen bacterial composition in favor of improving feedstuff 
Table 4 Relative mRNA expression of rumen epithelium genes in the most- $(n=6)$ and the least- $(n=6)$ efficient beef cattle on RFI testing for $70 \mathrm{~d}$ during the finishing period

\begin{tabular}{|c|c|c|c|c|c|c|c|c|c|}
\hline \multirow[t]{2}{*}{ Items } & \multicolumn{2}{|l|}{$\mathrm{RFI}^{1}$} & \multirow[t]{2}{*}{$\mathrm{SE}^{2}$} & \multicolumn{2}{|l|}{ Sex } & \multirow[t]{2}{*}{$\mathrm{SE}^{3}$} & \multicolumn{3}{|c|}{$P$-value } \\
\hline & Most-efficient animals & Least-efficient animals & & Steers & Heifers & & $\mathrm{RFI}$ & Sex & $\mathrm{RFI} \times \operatorname{sex}$ \\
\hline \multicolumn{10}{|c|}{ VFA absorption } \\
\hline SLC16A1 & 1.06 & 0.96 & 0.04 & 1.05 & 0.97 & 0.05 & 0.13 & 0.23 & 0.43 \\
\hline SLC16A3 & $1.18^{\mathrm{a}}$ & $1.04^{\mathrm{b}}$ & 0.03 & 1.11 & 1.11 & 0.03 & 0.02 & 0.89 & 0.96 \\
\hline$S L C 26 A 3$ & 1.00 & 0.81 & 0.06 & 0.98 & 0.83 & 0.07 & 0.06 & 0.11 & 0.75 \\
\hline HCAR1 & 1.08 & 1.12 & 0.05 & 1.07 & 1.13 & 0.06 & 0.65 & 0.47 & 0.18 \\
\hline SLC9A1 & 1.05 & 1.04 & 0.01 & 1.03 & 1.06 & 0.01 & 0.81 & 0.08 & 0.04 \\
\hline SLC9A2 & $1.06^{\mathrm{b}}$ & $1.14^{\mathrm{a}}$ & 0.02 & 1.09 & 1.11 & 0.02 & 0.01 & 0.48 & $<0.01$ \\
\hline SLC9A3 & 1.09 & 1.11 & 0.05 & 1.13 & 1.07 & 0.05 & 0.74 & 0.44 & 0.12 \\
\hline APPBP2 & 1.01 & 1.03 & 0.04 & 1.01 & 1.02 & 0.04 & 0.80 & 0.83 & 0.11 \\
\hline HIF1A & 1.05 & 1.04 & 0.01 & 1.06 & 1.03 & 0.01 & 0.69 & 0.12 & 0.01 \\
\hline \multicolumn{10}{|c|}{ VFA metabolism } \\
\hline ACSS1 & 1.12 & 1.23 & 0.14 & 1.25 & 1.10 & 0.15 & 0.57 & 0.47 & 0.56 \\
\hline ACSS2 & 0.99 & 0.95 & 0.05 & 0.98 & 0.96 & 0.06 & 0.54 & 0.80 & 0.60 \\
\hline ACO1 & 0.69 & 0.69 & 0.02 & 0.70 & 0.68 & 0.02 & 0.95 & 0.62 & 0.08 \\
\hline ACO2 & 1.07 & 1.06 & 0.01 & 1.07 & 1.06 & 0.01 & 0.42 & 0.86 & 0.02 \\
\hline PCCA & 1.04 & 1.01 & 0.03 & 0.99 & 1.06 & 0.03 & 0.32 & 0.07 & 0.73 \\
\hline SLC25A20 & 1.11 & 1.05 & 0.03 & $1.12^{\mathrm{a}}$ & $1.04^{b}$ & 0.03 & 0.11 & 0.04 & 0.17 \\
\hline \multicolumn{10}{|l|}{ Ketogenesis } \\
\hline ACADS & 1.05 & 1.00 & 0.02 & 1.01 & 1.04 & 0.03 & 0.12 & 0.41 & 0.33 \\
\hline ACAT1 & 1.17 & 1.06 & 0.04 & 1.13 & 1.09 & 0.05 & 0.09 & 0.46 & 0.45 \\
\hline HMGCL & $1.10^{\mathrm{a}}$ & $1.01^{\mathrm{b}}$ & 0.03 & 1.04 & 1.06 & 0.03 & 0.04 & 0.53 & 0.44 \\
\hline $\mathrm{BDH} 1$ & 1.04 & 0.98 & 0.03 & 1.02 & 1.00 & 0.03 & 0.13 & 0.59 & 0.04 \\
\hline HMGCS2 & $1.16^{\mathrm{a}}$ & $0.99^{b}$ & 0.06 & 1.11 & 1.04 & 0.05 & 0.04 & 0.37 & 0.47 \\
\hline TECR & 1.05 & 1.04 & 0.02 & 1.05 & 1.04 & 0.03 & 0.83 & 0.60 & 0.08 \\
\hline \multicolumn{10}{|c|}{ Pyruvate Metabolism } \\
\hline$\angle D H A$ & $1.03^{\mathrm{a}}$ & $0.97^{b}$ & 0.02 & 0.98 & 1.02 & 0.02 & 0.02 & 0.09 & 0.96 \\
\hline$\angle D H B$ & 1.07 & 0.99 & 0.03 & 1.00 & 1.06 & 0.04 & 0.09 & 0.18 & 0.83 \\
\hline PDHA1 & $1.09^{b}$ & $1.18^{\mathrm{a}}$ & 0.02 & 1.13 & 1.14 & 0.03 & 0.02 & 0.70 & 0.02 \\
\hline$P C$ & 1.04 & 1.02 & 0.03 & 1.01 & 1.06 & 0.03 & 0.74 & 0.20 & 0.45 \\
\hline \multicolumn{10}{|c|}{ Other metabolic pathways } \\
\hline PPARA & 1.27 & 1.25 & 0.05 & 1.25 & 1.27 & 0.06 & 0.80 & 0.85 & 0.79 \\
\hline PPARG & 1.00 & 1.00 & 0.02 & 0.98 & 1.02 & 0.02 & 0.88 & 0.14 & 0.66 \\
\hline PPARD & $1.07^{\mathrm{a}}$ & $0.99^{b}$ & 0.02 & 1.01 & 1.04 & 0.02 & 0.01 & 0.18 & 0.37 \\
\hline FFAR2 & 1.04 & 0.93 & 0.04 & $0.87^{b}$ & $1.11^{\mathrm{a}}$ & 0.05 & 0.09 & $<0.01$ & 0.02 \\
\hline RGS5 & 1.02 & 1.06 & 0.09 & 0.99 & 1.10 & 0.11 & 0.75 & 0.38 & 0.51 \\
\hline NQO1 & 1.14 & 1.04 & 0.04 & 1.06 & 1.11 & 0.05 & 0.12 & 0.41 & 0.80 \\
\hline \multicolumn{10}{|c|}{ Immune/inflammation-response } \\
\hline TLR2 & 1.02 & 0.97 & 0.02 & 0.98 & 1.01 & 0.03 & 0.15 & 0.41 & 0.18 \\
\hline TLR4 & 1.09 & 1.15 & 0.07 & 1.09 & 1.14 & 0.08 & 0.56 & 0.57 & 0.68 \\
\hline
\end{tabular}

Means with different superscripts $\left({ }^{\mathrm{a}, \mathrm{b}}\right)$ within row represent differences among overall RFI or sex effects $(P \leq 0.05)$

${ }^{1} R F I$ residual feed intake

${ }^{2} S E$ standard error of the mean for RFI effect

${ }^{3} S E$ standard error of the mean for sex effect 

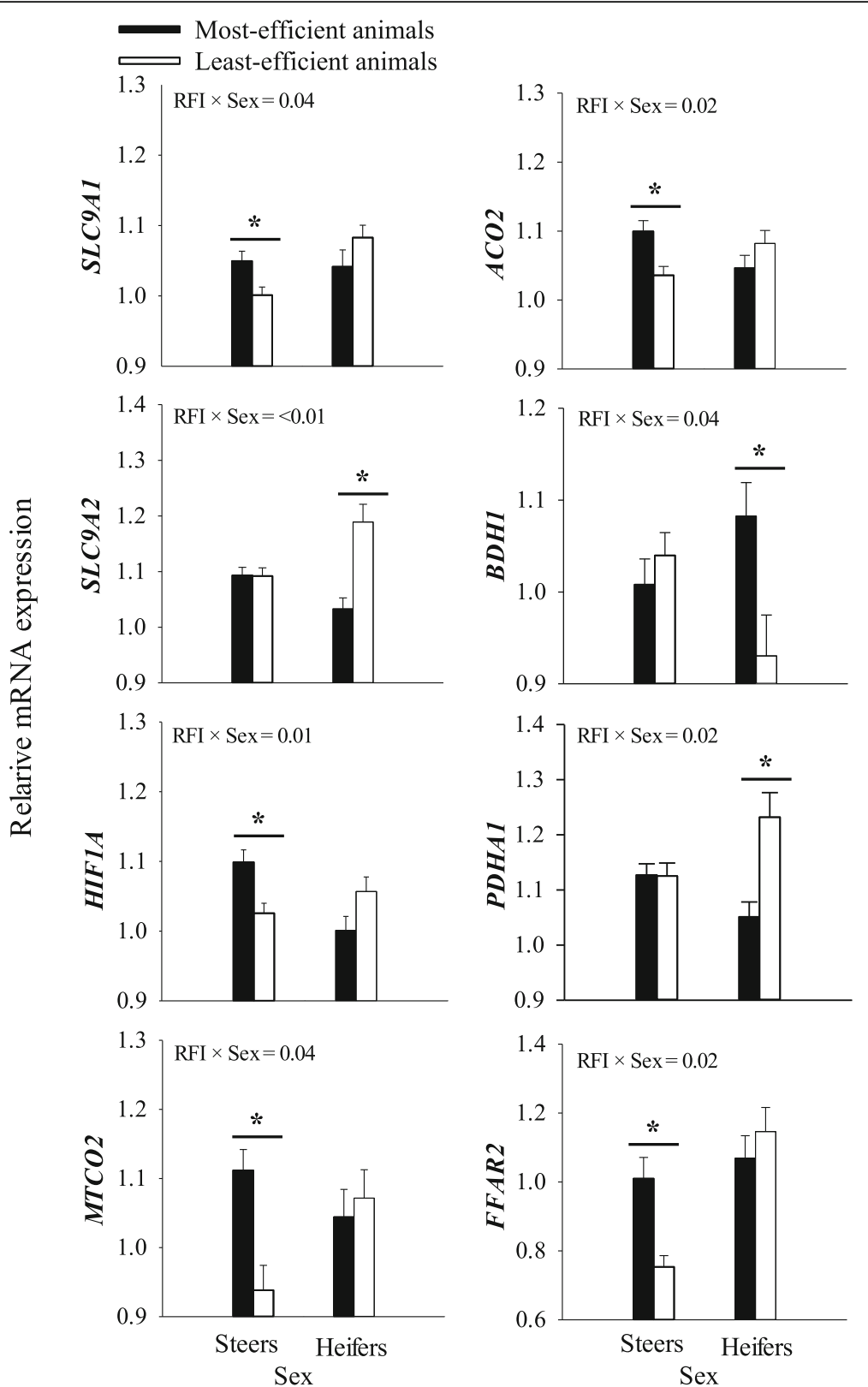

Fig. 1 Significant RFI and sex interactions $\left({ }^{*} P \leq 0.05\right)$ on relative mRNA expression of rumen epithelium genes in the most- $(n=6)$ and the least$(n=6)$ efficient beef cattle on RFI testing for $70 \mathrm{~d}$ during the finishing period

digestibility [38, 39], but none of those studies investigated whether sex, i.e. steers vs. heifers, would impact bacterial profile. The greater abundance of $F$. succinogenes (290\%) and E. ruminantium (218\%) in the most-efficient animals could have been associated with improvements in fiber degradation and feed digestibility. In the same line, Elolimy et al. [27] reported that the most-efficient dairy cows tended to have greater F. succinogenes around calving. F. succinogenes, a strictly anaerobic Gram-negative bacterium, is one of the most-important cellulose-degrading bacteria in the rumen, and ferments cellulose, xylan, cellobiose, and glucose to generate succinate, acetate and formate [40]. E. ruminantium, a Gram-positive bacteria, also plays a cellulolytic role in the rumen [41]. A better ability to ferment fiber through greater abundance $F$. succinogenes and $E$. ruminantium is supported by previous reports showing that the most-efficient beef bulls and heifers had greater rates of $\mathrm{DM}, \mathrm{OM}, \mathrm{NDF}$, protein, and TDN digestibility $[4,5] . M$. elsdenii, a Gram negative bacterium, utilizes lactate to produce butyrate and propionate by reverse $\beta$-oxidation [15]. Additionally, E. ruminantium produces butyrate through 
cellulose degradation [11]. In a recent study, Elolimy et al. [27] found that the most-efficient dairy cows tended to have greater $M$. elsdenii around calving. Therefore, the greater relative abundance of $M$. elsdenii and E. ruminantium in the most-efficient cattle in the current study could have led to increases in the molar proportion of butyrate and propionate in the rumen. In support of this speculation, Muya et al. [42] reported that neonatal dairy bulls and heifers receiving a 50-mL oral dose of $M$. elsdenii at $14 \mathrm{~d}$ of age had greater intraruminal butyrate production and plasma $\beta$-hydroxybutyrate (BHBA) at weaning (42 d of age).

Several lines of evidence indicate that the most-efficient cattle and sheep have greater butyrate, propionate, and propionate:acetate ratio in the rumen $[7,43]$. Enhancing the production of butyrate and propionate in the rumen is of physiologic significance for increasing energy retention from the feed since butyrate is metabolized by the ruminal epithelium to BHBA, whereas propionate is the main precursor for hepatic gluconeogenesis [44, 45]. Thus, although ruminal VFA concentrations were not measured in this study, we speculate that the most-efficient animals may have had greater levels of butyrate and propionate partly in response to the greater abundance of M. elsdenii and E. ruminantium in the rumen. Due to its role in the removal of lactate, $M$. elsdenii also helps maintain ruminal $\mathrm{pH}$ and control lactic acidosis [46]. Several studies observed a dramatic decrease in cellulolytic bacteria such as F. succinogenes, Ruminococcus albus, and Ruminococcus flavefaciens, but an increase in amylolytic species, e.g. $S$. amylolytica and Ruminobacter amylophilus, under low ruminal $\mathrm{pH}$ conditions such as subacute ruminal acidosis (SARA) [14, 47]. Therefore, greater M. elsdenii abundance in the most-efficient cattle in the present study may have helped control ruminal $\mathrm{pH}$, in turn facilitating the growth of cellulolytic $F$. succinogenes and E. ruminantium instead of amylolytic species such as $S$. amylolytica.

The discrepancy between a greater abundance of $3 \mathrm{im}$ portant bacterial species and lower total bacterial population density in the most-efficient cattle could be partly attributed to the fact we only measured a small number of bacterial species. Therefore, future studies to elucidate how shifts in rumen microbiota and its fermentation patterns are associated with RFI divergence in finishing beef cattle are necessary. Because bacteria comprise 95\% of the whole ruminal microbial community and contribute the most to feedstuff digestion, a lower density of total bacteria could be taken as indication that digestive function might be compromised in the most-efficient animals [48]. Despite that, other studies revealed that feed-efficient beef bulls and heifers had higher feed digestibility for DM, OM, NDF, protein, and TDN $[4,5]$. This suggests that $16 \mathrm{~S}$ gene copy numbers may not reflect the actual capacity of feed digestion in efficient cattle. The lower total bacterial density observed in the most-efficient cattle could have been attributed to lower DMI detected during the study since it is known that microbial growth is strongly correlated with the level of voluntary DMI [49]. Decreasing DMI would slow down the ruminal passage rate which is associated with increased energy costs of maintenance for microbes [50] leading to a decrease in the overall microbial population in feed-efficient cattle in the current study.

\section{Ruminal epithelium gene expression VFA absorption and metabolism}

Shifts in ruminal bacterial species in the most-efficient animals in the present study and the expected changes in VFA profile were possibly associated with alteration in the expression of various genes in ruminal epithelium. Expression of SLC16A3, SLC26A3, and HIF1A participate in the transepithelial absorption of VFA $[18,51]$. Butyrate induced the transcription of SLC16A3, SLC26A3, and HIF1A in sheep ruminal epithelia, human breast cancer, and colon cell lines [52-54]. Therefore, the concurrent increase in the expression of those genes in the most-efficient animals might have been part of functional adaptations to enhance absorptive capacity in the most-efficient cattle. As such, molecular adaptations could have helped compensate for the lower feed intake in the most-efficient animals. The greater rate of VFA uptake in response to upregulation of VFA absorption in the ruminal epithelium of the most-efficient animals could have led to increases in intracellular proton $\left(\mathrm{H}^{+}\right)$ load, hence, compromising intracellular $\mathrm{pH}\left(\mathrm{pH}_{\mathrm{i}}\right)$ [55]. The $\mathrm{Na}^{+} / \mathrm{H}^{+}$exchangers such as $S L C 9 A 1$, which localize to the stratum granulosum of ruminal epithelium, play a central role in maintaining constant $\mathrm{pH}_{\mathrm{i}}$ in rumen epithelial cells [56]. The greater expression of SLC9A1 in the most-efficient steers could have been of physiologic importance because enhanced epithelial VFA uptake would have increased the intracellular $\mathrm{H}^{+}$load. As such, the response in $S L C 9 A 1$ is suggestive of better functional capacity for the ruminal epithelium in the most-efficient cattle to maintain $\mathrm{pH}_{\mathrm{i}} \cdot A C O 2$ is an iron-sulfur enzyme that stimulates the conversion of citrate to isocitrate, an early step in the tricarboxylic acid (TCA) cycle [57]. Therefore, upregulation of $\mathrm{ACO} 2$ in the ruminal epithelium of the most-efficient steers would be predicted to enhance activity of the TCA cycle, leading to greater energy production in ruminal epithelial cells.

\section{Ketogenesis}

The fact that the mRNA expression of $A C A T 1, H M G C L$, $B D H 1$, and $H M G C S 2$ was greater in the most-efficient animal suggests that epithelial butyrate utilization was more active in those animals, likely due to greater ruminal butyrate availability as shown by Guan et al. [58]. Greater 
butyrate production in the most-efficient animals is supported by the greater abundance of M. elsdenii and E. ruminantium in the rumen. Thus, the combined response in these genes suggests not only greater synthesis of hydroxybutyrate (BHBA) but potentially greater generation of ATP from metabolism of acetoacetyl-CoA. Because the reaction catalyzed by $A C A T 1$ is bi-directional, the greater expression of ACAT1 in the most-efficient animals could have allowed for an increase in metabolism of acetyl-CoA generated from butyrate oxidation toward acetoacetyl-CoA [59]. The enzymes encoded by HMGCS2 and HMGCL catalyze synthesis of hydroxyl-methyl-glutaryl-CoA and acetoacetate which can then be utilized by $B D H 1$ to generate BHBA [ 60 , 61]. The fact that HMGCS2 is transcriptionally-regulated suggests that most-efficient animals likely had an enhanced activity of the enzyme such that the main end-product BHBA was exported into the portal vein for utilization by peripheral tissues. Clearly, the upregulation of ACAT1 also would have allowed for utilization of acetoacetylCoA for synthesis of ATP, i.e. re-circulation of BHBA back into ruminal epithelium through the bi-directional $B D H 1$ enzyme would have generated acetoacetyl-CoA followed by cleavage into 2 acetyl-CoA for further metabolism within the TCA cycle. The current study revealed no differences in TECR expression between RFI groups. However, Kong et al. [8] reported that TECR had greater expression in the ruminal epithelium of the most-efficient steers. This discrepancy between studies was likely driven by the greater number of animals ( 9 steers/group) used by Kong et al. [8], which may have allowed them to detect smaller differences in epithelial TECR expression between RFI groups.

\section{Pyruvate metabolism}

In coordination with the ketogenic genes, the upregulation of epithelial $L D H A, L D H B$, and FFAR2 in the most-efficient cattle could have ensured that energy production is maintained in spite of lower feed intake. Lactate dehydrogenase A (LDHA) encodes a cytoplasmic enzyme catalyzing the conversion of pyruvate to lactate and $\mathrm{NAD}^{+}$[62]. Lactate is then transported into the mitochondria for conversion into pyruvate and NADH via $L D H B$, promoting pyruvate oxidation in the TCA cycle and generation of reducing equivalents (e.g. $\mathrm{NADH}$ ), which, in turn, can promote mitochondrial ATP synthesis and energy production [63]. The PDHA1 gene encodes the subunit of the active site of the pyruvate dehydrogenase (PDH) enzyme that converts pyruvate to acetyl-CoA during glucose, lactate, or amino acid oxidation, and helps in the production of ATP [64]. The expression of FFAR2 in ruminal epithelium of cattle is activated by luminal propionate concentration, hence, enhancing its metabolism to pyruvate via succinyl-CoA [65]. Thus, the greater FFAR2 in most-efficient animals supports the possibility that higher amounts of ruminal propionate were produced, hence, upregulating FFAR2.

The lower expression of PDHA1 in the most-efficient cattle supports the notion that there was greater production of ruminal butyrate. Previous reports detected an increase in epithelial $L D H A$ and a decrease in PDHA1 expression in beef and dairy cattle due to feed restriction or increased butyrate production in the rumen, respectively [22]. It was speculated that such responses would result in greater acetyl-CoA supply. Taken together, changes in the expression of $L D H A, L D H B, F F A R 2$, and PDHA1 in the ruminal epithelium of the most-efficient animals offers further support to the idea that those animals were able to more-efficiently capture energy from ruminal VFA.

\section{Nuclear receptors}

Among peroxisome proliferator-activated receptors measured in the current study, inducing PPARD could activate transcription of genes related to ketogenesis [66]. Therefore, we speculate that the upregulation of PPARD in the most-efficient animals was part of the transcriptional response that could have enhanced ketogenesis. This idea is supported in part by the upregulation of ACAT1, HMGCL, BDH1, and HMGCS2.

\section{Conclusions}

An improvement of feed efficiency in the most-efficient cattle occurs in part through greater abundance of major bacterial species associated with fiber and non-fiber carbohydrate digestion that adhere to the ruminal solids-fraction, for example but not limited to F. succinogenes, $M$. elsdenii and E. ruminantium. The end-result is greater production of essential energy substrates for cattle (butyrate and propionate), which in turn activate metabolic pathways in ruminal epithelium to enhance VFA absorption and ketogenesis. Together, these adaptations would provide a greater energy supply to the host, which was partly reflected in the better carcass characteristics including $\mathrm{HCW}, \mathrm{KPH}$, and REA. The lack of association between RFI and sex on growth traits, carcass traits, and ruminal bacteria profiles underscore the independence of RFI. Overall, better feed efficiency as determined by RFI is at associated with unique adaptations in the ruminal microbiota and epithelium gene expression.

\section{Additional files}

Additional file 1: Table S1. Primers sequence of targeted rumen bacterial species. Table S2. Metabolic pathway, gene symbol, and gene name of genes measured in rumen epithelium. Table S3. Primers 
sequence for rumen epithelial genes. Table S4. Real-time RT-PCR performance of genes measured in rumen epithelium. (DOCX $39 \mathrm{~kb}$ )

\section{Abbreviations}

ADG: Average daily gain; BW: Body weight; DM: Dry matter; DMl: Dry matter intake; HCW: Hot carcass weight; KPH: Kidney, pelvic, and heart; NDF: Neutral detergent fiber; OM: Organic matter; REA: Ribeye area; RFI: Residual feed intake; TDN: Total digestible nutrients

\section{Acknowledgements}

Ahmed A. Elolimy is a recipient of a PhD fellowship from Missions Sector, Higher Education Ministry, Egypt to perform his PhD studies at the University of Illinois (Urbana). Mohamed K. Abdelmegeid is a recipient of a postdoctoral fellowship from Missions Sector, Higher Education Ministry, Egypt.

\section{Availability of data and materials}

The datasets during and/or analyzed during the current study available from the corresponding authors on reasonable request.

\section{Authors' contributions}

$J \mathrm{~J}$ and DS designed the experiments; AAE, MKA, and JCM performed analyses and analyzed data; AAE wrote the manuscript. All authors read and approved the final version of the manuscript.

\section{Authors' information}

Ahmed A. Elolimy is PhD candidate, Department of Animal Sciences, University of Illinois, Urbana, Illinois, 61,801, USA. Mohamed K. Abdelmegeid is Lecturer in the Faculty of Veterinary Medicine, Kafrelsheikh University, Kafr El-Shaikh 33,516, Egypt. Joshua C. McCann is Assistant Professor in the Department of Animal Sciences, University of Illinois, Urbana, Illinois, 61,801, USA. Daniel W. Shike Loor is Associate Professor in the Department of Anima Sciences, University of Illinois, Urbana, Illinois, 61,801, USA. Juan J. Loor is Associate Professor in the Department of Animal Sciences, University of Illinois, Urbana, Illinois, 61,801, USA.

\section{Ethics approval}

All procedures for this study (protocol no. 12009) were approved by the Institutional Animal Care and Use Committee of the University of Illinois.

\section{Consent for publication}

Not applicable.

\section{Competing interests}

The authors declare that they have no competing interests.

\section{Author details}

${ }^{1}$ Mammalian NutriPhysioGenomics, Department of Animal Sciences, University of Illinois, Urbana, IL, USA. ²Department of Animal Sciences, University of Illinois, Urbana, IL, USA. ${ }^{3}$ Faculty of Veterinary Medicine, Kafrelsheikh University, Kafr El-Shaikh 33516, Egypt. ${ }^{4}$ Division of Nutritional Sciences, Illinois Informatics Institute, University of Illinois, Urbana, IL, USA.

\section{Received: 7 April 2018 Accepted: 13 August 2018}

\section{Published online: 24 September 2018}

\section{References}

1. Koch RM, Swiger LA, Chambers D, Gregory KE. Efficiency of feed use in beef cattle. J Anim Sci. 1963;22:486-94.

2. Seabury $C M$, Oldeschulte $D L$, Saatchi $M$, Beever JE, Decker JE, Halley YA, et al. Genome-wide association study for feed efficiency and growth traits in U.S. beef cattle. BMC Genomics. 2017:18:386

3. Herd RM, Oddy VH, Richardson EC. Biological basis for variation in residual feed intake in beef cattle. 1. Review of potential mechanisms. Aust J Exp Agric. 2004:44:423-30.

4. Bonilha SFM, Branco RH, Mercadante MEZ, JN DSGC, Monteiro FM, Ribeiro EG. Digestion and metabolism of low and high residual feed intake Nellore bulls. Trop Anim Health Prod. 2017;49:529-35.

5. McDonnell RP, Hart KJ, Boland TM, Kelly AK, McGee M, Kenny DA. Effect of divergence in phenotypic residual feed intake on methane emissions, ruminal fermentation, and apparent whole-tract digestibility of beef heifers across three contrasting diets. J Anim Sci. 2016;94:1179-93.

6. McCann JC, Wiley LM, Forbes TD, Rouquette FM Jr, Tedeschi LO. Relationship between the rumen microbiome and residual feed intakeefficiency of Brahman bulls stocked on bermudagrass pastures. PLoS One. 2014:9:e91864.

7. Liang YS, Li GZ, Li XY, Lu JY, Li FD, Tang DF, et al. Growth performance, rumen fermentation, bacteria composition, and gene expressions involved in intracellular $\mathrm{pH}$ regulation of rumen epithelium in finishing $\mathrm{Hu}$ lambs differing in residual feed intake phenotype. J Anim Sci. 2017:95:1727-38.

8. Kong RS, Liang G, Chen Y, Stothard P, Guan le L. Transcriptome profiling of the rumen epithelium of beef cattle differing in residual feed intake. BMC Genomics. 2016;17:592.

9. Kern RJ, Lindholm-Perry AK, Freetly HC, Snelling WM, Kern JW, Keele JW, et al. Transcriptome differences in the rumen of beef steers with variation in feed intake and gain. Gene. 2016;586:12-26.

10. Wu CW, Spike T, Klingeman DM, Rodriguez M, Bremer VR, Brown SD. Generation and characterization of acid tolerant Fibrobacter succinogenes S85. Sci Rep. 2017;7:2277.

11. Kozakai K, Nakamura T, Kobayashi Y, Tanigawa T, Osaka I, Kawamoto S, et al. Effect of mechanical processing of corn silage on in vitro ruminal fermentation, and in situ bacterial colonization and dry matter degradation. Can J Anim Sci. 2007;87:259-67.

12. Matsui H, Ogata K, Tajima K, Nakamura M, Nagamine T, Aminov Rl, et al. Phenotypic characterization of polysaccharidases produced by four Prevotella type strains. Curr Microbiol. 2000;41:45-9.

13. Moon CD, Pacheco DM, Kelly WJ, Leahy SC, Li D, Kopecny J, et al. Reclassification of Clostridium proteoclasticum as Butyrivibrio proteoclasticus comb. nov., a butyrate-producing ruminal bacterium. Int J Syst Evol Microbiol. 2008;58:2041-5.

14. Khafipour E, Li S, Plaizier JC, Krause DO. Rumen microbiome composition determined using two nutritional models of subacute Ruminal acidosis. Appl Environ Microbiol. 2009;75:7115-24.

15. Chowdhury NP, Kahnt J, Buckel W. Reduction of ferredoxin or oxygen by flavin-based electron bifurcation in Megasphaera elsdenii. FEBS J. 2015;282: 3149-60.

16. Hungate RE. The rumen and its microbes. NewYork: AcademicPress; 1966.

17. Zhu W, Wei Z, Xu N, Yang F, Yoon I, Chung Y, et al. Effects of Saccharomyces cerevisiae fermentation products on performance and rumen fermentation and microbiota in dairy cows fed a diet containing low quality forage. J Anim Sci Biotechnol. 2017;8:36.

18. Stumpff F. A look at the smelly side of physiology: transport of short chain fatty acids. Pflugers Arch. 2018;470(4):571-98.

19. Kern RJ, Zarek CM, Lindholm-Perry AK, Kuehn LA, Snelling WM, Freetly HC, et al. Ruminal expression of the NQ01, RGS5, and ACAT1 genes may be indicators of feed efficiency in beef steers. Anim Genet. 2017;48:90-2.

20. Minuti A, Palladino A, Khan MJ, Alqarni S, Agrawal A, Piccioli-Capelli F, et al. Abundance of ruminal bacteria, epithelial gene expression, and systemic biomarkers of metabolism and inflammation are altered during the peripartal period in dairy cows. J Dairy Sci. 2015;98:8940-51.

21. Xiang R, Oddy VH, Archibald AL, Vercoe PE, Dalrymple BP. Epithelial, metabolic and innate immunity transcriptomic signatures differentiating the rumen from other sheep and mammalian gastrointestinal tract tissues. PeerJ. 2016;4:e1762.

22. O'Shea E, Waters SM, Keogh K, Kelly AK, Kenny DA. Examination of the molecular control of ruminal epithelial function in response to dietary restriction and subsequent compensatory growth in cattle. J Anim Sci Biotechnol. 2016;7:53.

23. McCann JC, Luan S, Cardoso FC, Derakhshani H, Khafipour E, Loor JJ. Induction of subacute Ruminal acidosis affects the Ruminal microbiome and epithelium. Front Microbiol. 2016;7:701.

24. Basarab JA, Colazo MG, Ambrose DJ, Novak S, McCartney D, Baron VS. Residual feed intake adjusted for backfat thickness and feeding frequency is independent of fertility in beef heifers. Can J Anim Sci. 2011:91:573-84.

25. Derakhshani H, Tun HM, Cardoso FC, Plaizier JC, Khafipour E, Loor JJ. Linking Peripartal dynamics of Ruminal microbiota to dietary changes and production parameters. Front Microbiol. 2016;7:2143.

26. Yu Z, Morrison M. Improved extraction of PCR-quality community DNA from digesta and fecal samples. BioTechniques. 2004;36:808-12.

27. Elolimy AA, Arroyo JM, Batistel F, lakiviak MA, Loor J J. Association of residua feed intake with abundance of ruminal bacteria and biopolymer 
hydrolyzing enzyme activities during the peripartal period and early lactation in Holstein dairy cows. J Anim Sci Biotechnol. 2018;9:43.

28. Maeda H, Fujimoto C, Haruki Y, Maeda T, Kokeguchi S, Petelin M, et al. Quantitative real-time PCR using TaqMan and SYBR green for Actinobacillus actinomycetemcomitans, Porphyromonas gingivalis, Prevotella intermedia, tetQ gene and total bacteria. FEMS Immunol Med Microbiol. 2003;39:81-6

29. Fliegerova K, Tapio I, Bonin A, Mrazek J, Callegari ML, Bani P, et al. Effect of DNA extraction and sample preservation method on rumen bacterial population. Anaerobe. 2014;29:80-4.

30. Ramirez-Farias C, Slezak K, Fuller Z, Duncan A, Holtrop G, Louis P. Effect of inulin on the human gut microbiota: stimulation of Bifidobacterium adolescentis and Faecalibacterium prausnitzii. Br J Nutr. 2009;101:541-50.

31. Zhou M, Hernandez-Sanabria E, Guan LL. Assessment of the microbial ecology of ruminal methanogens in cattle with different feed efficiencies. Appl Environ Microbiol. 2009:75:6524-33.

32. Naeem A, Drackley JK, Stamey J, Loor JJ. Role of metabolic and cellular proliferation genes in ruminal development in response to enhanced plane of nutrition in neonatal Holstein calves. J Dairy Sci. 2012;95:1807-20.

33. Livak KJ, Schmittgen TD. Analysis of relative gene expression data using real-time quantitative PCR and the 2(-Delta Delta C(T)) method. Methods. 2001;25:402-8.

34. Robinson DL, Oddy VH. Genetic parameters for feed efficiency, fatness, muscle area and feeding behaviour of feedlot finished beef cattle. Livest Prod Sci. 2004;90:255-70

35. Santana MHA, Rossi P, Almeida R, Cucco DC. Feed efficiency and its correlations with carcass traits measured by ultrasound in Nellore bulls. Livest Sci. 2012;145:252-7.

36. Ahola JK, Skow TA, Hunt CW, Hill RA. Relationship between residual feed intake and end product palatability in longissimus steaks from steers sired by Angus bulls divergent for intramuscular fat expected progeny difference. Prof Anim Sci. 2011;27:109-15.

37. Davis ME, Lancaster PA, Rutledge JJ, Cundiff LV. Life cycle efficiency of beef production: IX. Relationship between residual feed intake of heifers and cow efficiency ratios based on harvest, carcass, and wholesale cut weight outputs. J Anim Sci. 2018;96:430-43.

38. Li F, Guan LL. Metatranscriptomic profiling reveals linkages between the active rumen microbiome and feed efficiency in beef cattle. Appl Environ Microbiol. 2017:83:e00061-17.

39. Myer PR, Smith TP, Wells JE, Kuehn LA, Freetly HC. Rumen microbiome from steers differing in feed efficiency. PLoS One. 2015;10:e0129174.

40. Ransom-Jones E, Jones DL, McCarthy AJ, McDonald JE. The Fibrobacteres: an important phylum of cellulose-degrading bacteria. Microb Ecol. 2012;63: 267-81

41. Maia MR, Chaudhary LC, Figueres L, Wallace RJ. Metabolism of polyunsaturated fatty acids and their toxicity to the microflora of the rumen. Antonie Van Leeuwenhoek. 2007;91:303-14.

42. Muya MC, Nherera FV, Miller KA, Aperce CC, Moshidi PM, Erasmus LJ. Effect of Megasphaera elsdenii NCIMB 41125 dosing on rumen development, volatile fatty acid production and blood beta-hydroxybutyrate in neonatal dairy calves. J Anim Physiol Anim Nutr (Berl). 2015;99:913-8.

43. Shabat SK, Sasson G, Doron-Faigenboim A, Durman T, Yaacoby S, Berg Miller ME, et al. Specific microbiome-dependent mechanisms underlie the energy harvest efficiency of ruminants. ISME J. 2016;10:2958-72.

44. Russell JB, Wilson DB. Why are ruminal cellulolytic bacteria unable to digest cellulose at low pH? J Dairy Sci. 1996;79:1503-9.

45. Quigley JD 3rd, Caldwell LA, Sinks GD, Heitmann RN. Changes in blood glucose, nonesterified fatty acids, and ketones in response to weaning and feed intake in young calves. J Dairy Sci. 1991;74:250-7.

46. Ribeiro Junior CS, Messana JD, Granja-Salcedo YT, Canesin RC, Fiorentini G, San Vito E, et al. Parameters of fermentation and rumen microbiota of Nellore steers fed with different proportions of concentrate in fresh sugarcane containing diets. Arch Anim Nutr. 2016;70:402-15.

47. Petri RM, Forster RJ, Yang W, McKinnon JJ, McAllister TA. Characterization of rumen bacterial diversity and fermentation parameters in concentrate fed cattle with and without forage. J Appl Microbiol. 2012;112:1152-62.

48. Pitta DW, Kumar S, Vecchiarelli B, Shirley DJ, Bittinger K, Baker LD, et al. Temporal dynamics in the ruminal microbiome of dairy cows during the transition period. J Anim Sci. 2014:92:4014-22.

49. Febel $H$, Fekete $S$. Factors influencing microbial growth and the efficiency of microbial protein synthesis: a review. Acta Vet Hung. 1996;44:39-56.
50. Firkins JL. Maximizing microbial protein synthesis in the rumen. J Nutr. 1996; 126:1347s-54s.

51. Kirat D, Matsuda Y, Yamashiki N, Hayashi H, Kato S. Expression, cellular localization, and functional role of monocarboxylate transporter 4 (MCT4) in the gastrointestinal tract of ruminants. Gene. 2007;391:140-9.

52. Queiros O, Preto A, Pacheco A, Pinheiro C, Azevedo-Silva J, Moreira R, et al. Butyrate activates the monocarboxylate transporter MCT4 expression in breast cancer cells and enhances the antitumor activity of 3bromopyruvate. J Bioenerg Biomembr. 2012;44:141-53.

53. Alrefai WA, Wen X, Jiang W, Katz JP, Steinbrecher KA, Cohen MB, et al. Molecular cloning and promoter analysis of downregulated in adenoma (DRA). Am J Physiol Gastrointest Liver Physiol. 2007;293:G923-34.

54. Dengler F, Rackwitz R, Benesch F, Pfannkuche H, Gabel G. Both butyrate incubation and hypoxia upregulate genes involved in the ruminal transport of SCFA and their metabolites. J Anim Physiol Anim Nutr (Berl). 2015;99: 379-90.

55. Yan L, Zhang B, Shen Z. Dietary modulation of the expression of genes involved in short-chain fatty acid absorption in the rumen epithelium is related to short-chain fatty acid concentration and $\mathrm{pH}$ in the rumen of goats. J Dairy Sci. 2014;97:5668-75.

56. Yang $W$, Shen $Z$, Martens $H$. An energy-rich diet enhances expression of $\mathrm{Na}(+) / H(+)$ exchanger isoform 1 and 3 messenger RNA in rumen epithelium of goat. J Anim Sci. 2012;90:307-17.

57. Myers CR, Antholine WE, Myers JM. The pro-oxidant chromium(VI) inhibits mitochondrial complex I, complex II, and aconitase in the bronchial epithelium: EPR markers for Fe-S proteins. Free Radic Biol Med. 2010;49: 1903-15.

58. Guan LL, Nkrumah JD, Basarab JA, Moore SS. Linkage of microbial ecology to phenotype: correlation of rumen microbial ecology to cattle's feed efficiency. FEMS Microbiol Lett. 2008;288:85-91.

59. Gonzalez-Serrano AF, Pirro V, Ferreira CR, Oliveri P, Eberlin LS, Heinzmann J, et al. Desorption electrospray ionization mass spectrometry reveals lipid metabolism of individual oocytes and embryos. PLoS One. 2013;8:e74981.

60. Wang W, Li C, Li F, Wang X, Zhang X, Liu T, et al. Effects of early feeding on the host rumen transcriptome and bacterial diversity in lambs. Sci Rep. 2016;6:32479.

61. Ma L, Zhao M, Zhao LS, Xu JC, Loor JJ, Bu DP. Effects of dietary neutral detergent fiber and starch ratio on rumen epithelial cell morphological structure and gene expression in dairy cows. J Dairy Sci. 2017;100:3705-12.

62. Ivanov A, Mukhtarov M, Bregestovski P, Zilberter Y. Lactate effectively covers energy demands during neuronal network activity in neonatal hippocampal slices. Front Neuroenerg. 2011;3:2.

63. Valvona CJ, Fillmore HL, Nunn PB, Pilkington GJ. The regulation and function of lactate dehydrogenase a: therapeutic potential in brain tumor. Brain Pathol. 2016;26:3-17.

64. Johnson MT, Mahmood S, Hyatt SL, Yang HS, Soloway PD, Hanson RW, et al Inactivation of the murine pyruvate dehydrogenase (Pdha1) gene and its effect on early embryonic development. Mol Genet Metab. 2001;74:293-302.

65. Wang A, Akers RM, Jiang H. Short communication: presence of $G$ proteincoupled receptor 43 in rumen epithelium but not in the islets of Langerhans in cattle. J Dairy Sci. 2012;95:1371-5.

66. Shi HB, Zhang $\mathrm{CH}$, Zhao W, Luo J, Loor JJ. Peroxisome proliferator-activated receptor delta facilitates lipid secretion and catabolism of fatty acids in dairy goat mammary epithelial cells. J Dairy Sci. 2017;100:797-806.

67. Field TG. The marketing system. In: Beef production and management decisions. 5th ed. New York: Prentice Hall; 2007.

Ready to submit your research? Choose BMC and benefit from:

- fast, convenient online submission

- thorough peer review by experienced researchers in your field

- rapid publication on acceptance

- support for research data, including large and complex data types

- gold Open Access which fosters wider collaboration and increased citations

- maximum visibility for your research: over $100 \mathrm{M}$ website views per year

At $\mathrm{BMC}$, research is always in progress.

Learn more biomedcentral.com/submissions 